1・はじめに

騒音下の補僡に関する研究は、重要性が指摘されているにもかかわらず、いまだに明碓 な結論がなく、補聼器の適合也装用指導において判断に迷うことが少なくない。騒音に対 応する補䁃器として、従来から、低音域の減衰を外部スイッチで行なえる器種があったが 、败䁬者が遭遇する種々の㻴境强音に十分対応できるものではなかった。ところで、最近 プログラマブル㭪㱬器が登場し、環境騒音に応じて周波数特性を幅広く变更することが可 能となった。本研究では、騒音下の通切な周波数特性と利得の挨討を目的とした。

\title{
2. 対象と方法
}

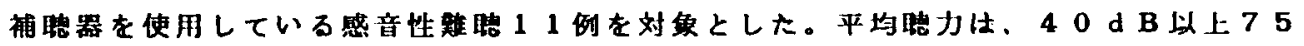
d B 以内である。

挨討した周波数特性は、团1に示したA、B、C、Dの4つの特性とし、耳掛形のプロ

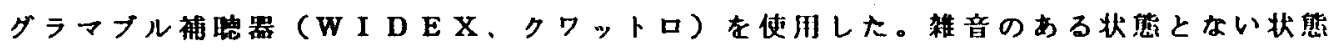
て、スピーカより女性の的読のテープ（新潮社カセットブック、向田邦子）を、被娭者の

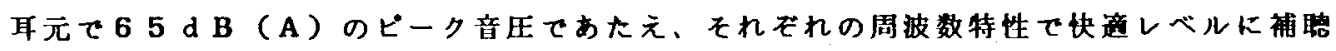
器の利得を調整させた。つぎに、4つの周波数特性について「話が良くかかる㮌位」を尋 ねた。

雑音の提示は、別のスピーカから行なった。使用した蓸音は、図 2 に示した 3 種の周波

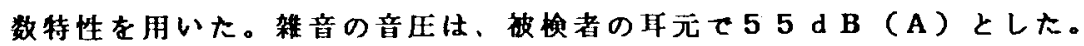

結果の検討は、1 1 例の平均值を用いて行なった。周波数特性の比較では、「話が良く わかる」㮌位の1位の閤波数特性に2 点、2 位の特性に1点を与元、全体を集計した。補

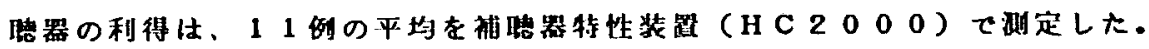

3 . 結果

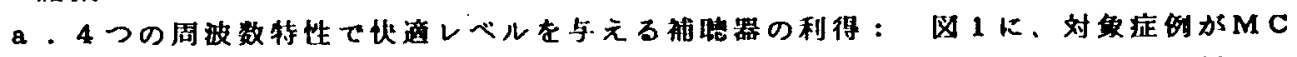
しと評価した利得周波数特性を示した。800 H z の利得が 4 つの周波数特性で近仪して いた。

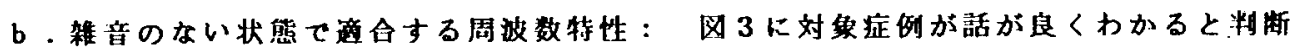
した周波数特性の評価点を示した。通合する特性は泟例間で買なっていたが、Bの特性が 最も好まれる傾向があった。

c . 雑音下の、4つの周波数特性で快適レベルを与元る補䀩器の利得：低周波数带、 中周波数带、高周波数带のいすれの雑音下でも、すべての周波数特性で、快通レベルを与 える補䁃器の利得は雜音がない埸合と一致していた。

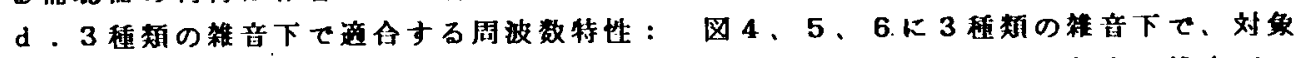
症例が話が良くわかると頖断した周波数特性の評価点を示した。低周波数带の雜音下て は、厸域強葍のD、Cの特性の評価が高く、高周波数带の雑音下では、低域強胭のB、A の特性の評価が高かった。中周波数带の﨎音下では、道合する周波数特性は症例により異 なり、一定の傾向を㒛めなかった。 


\section{4. 考察}

騷音のない状態では、会話音にたいして快適レベルを与える補䁬器の利得は、補䁬器の 周波数特性の美異にかかわらす、1000 $\mathrm{Hz}$ 付近で近似している。会話音の理歷に重要 で、かつ音声势力が強い $1000 \mathrm{~Hz}$ 付近の音王レベルが開連していると考えられる。ま た、雑音の有無にかかわらず快道レベルの評侕は、会話音のレベルによって判断される束 実は、補䁖器の装朋指瞋上重要であろう。

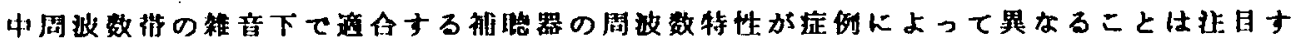

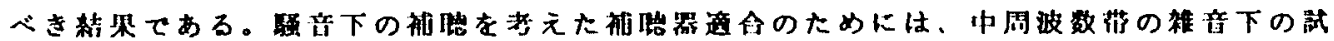
瞣と閭診が必要である。

因1.4種類の周波数特性と 块通レベルの利得

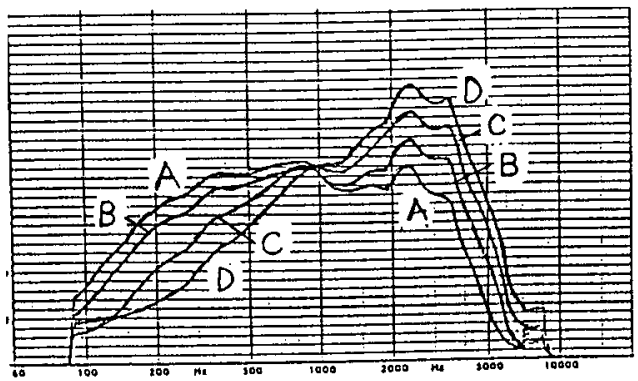

园3

\begin{tabular}{|c|c|}
\hline 閭波数特性 & 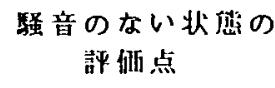 \\
\hline A & $\dashv 9$ \\
\hline B & -12 \\
\hline C & $\longrightarrow 7$ \\
\hline $\mathrm{D}$ & -15 \\
\hline
\end{tabular}

因 5

\begin{tabular}{|c|c|}
\hline 周波数特性 & $\begin{array}{c}\text { 中周波数衔雑音下の } \\
\text { 評斫点 }\end{array}$ \\
\hline A & $\longrightarrow 6$ \\
\hline B & $\longrightarrow 8$ \\
\hline C & -19 \\
\hline D & $\longrightarrow 10$ \\
\hline
\end{tabular}

因2.3 種類の雑音の周波数分布 (破線は的読音を示す)

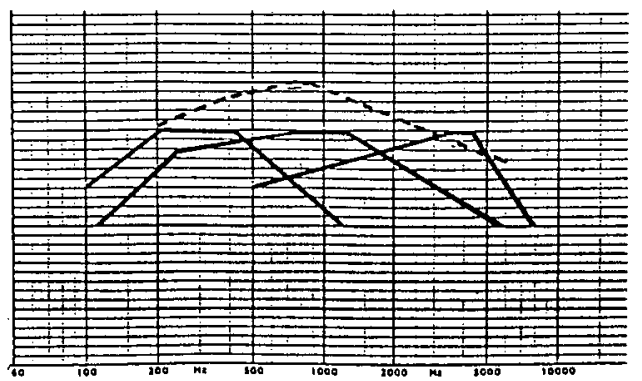

脑 4

\begin{tabular}{|c|c|}
\hline 周波数特姓 & 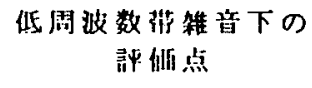 \\
\hline A & -13 \\
\hline B & -13 \\
\hline C & $\longrightarrow$ \\
\hline D & -16 \\
\hline
\end{tabular}

图 6

\begin{tabular}{|c|c|}
\hline 閭波数特䏭 & 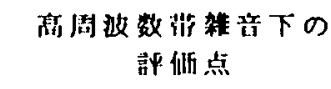 \\
\hline A & -14 \\
\hline B & $\longrightarrow 15$ \\
\hline C & $\longrightarrow 4$ \\
\hline D & 0 \\
\hline
\end{tabular}

